\title{
How to prevent youth crime in Macedonia?
}

\author{
Blerta Ahmedi Arifi \\ PhD Cand. PhD Assistant on Criminal Law, Faculty of Law - South East European University, \\ Tetovo - Republic of Macedonia
}

\begin{abstract}
This research paper analyzes the policy of Republic of Macedonia on preventing youth crime. It gives a focus on some main points of the topic, such as: The institutional measures there are implemented to prevent youth crime, such as the legislation and the national strategies of the state; The analysis of the special and general preventive effect of the penal sanctions for children. Also, there is presented the analysis of the influence of some social factors as preventive measures for the youth delinquency, such as: The education system; The free time of the youth people; The role of their family; The economic level of the children's families; The circle of persons who they accompany and the access to the mass media. During this study there are used some methods, such as: The literature review for this topic and the interpretation of the legal provisions for youth crime; The survey and the interviews made with secondary school pupils and the comparative method used for some social factors, as some like more relevant beside others for preventing the youth crime. The results and conclusions of this research paper will contribute on finding the most relevant measures on preventing the youth/child crime in Macedonia.
\end{abstract}

Keywords: Prevention of youth crime, preventive policy, measures, social factors.

\section{Introduction}

The preventive characteristics of the criminal sanctions is expanded in two areas: On the General prevention of the crime and on its special prevention. The general Prevention - signifies the influence to the citizens, and in particular on the children or youth people to not commit crimes. This is achieved by causing fear to them from the sentenced penalties to the incriminating offenders. And, the Special prevention signifies on preventing the perpetrator of the crime to (not) do again the same or another crime.

In the following, there are presented the data on the number of children convicted, for the time period 2006-2015, based on the data published by the State Statistical Office of the Republic of Macedonia.

The number of convicted persons in Republic of Macedonia during the period of 2006-2015

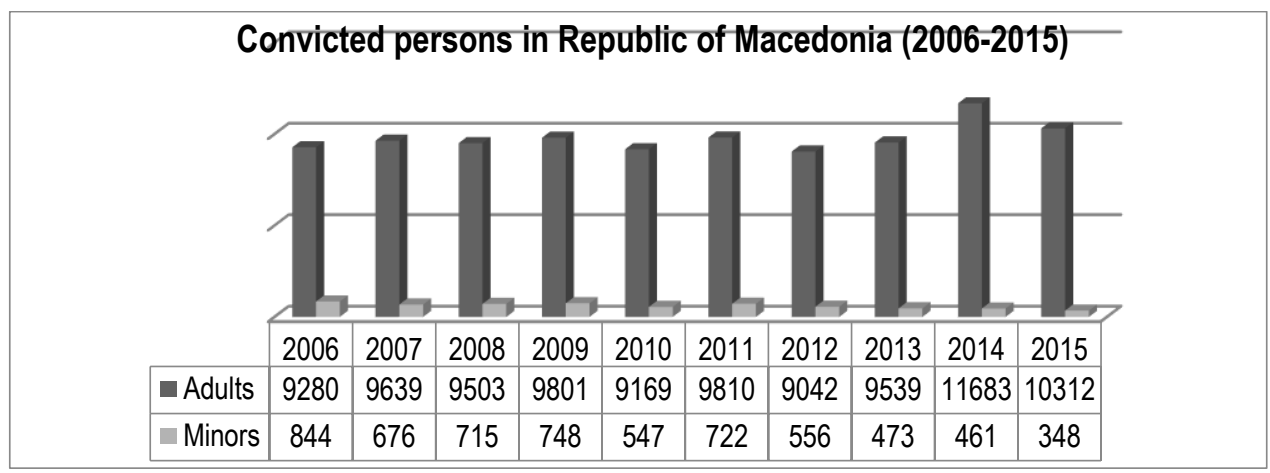

Table 1. (State Statistical Office of the Republic of Macedonia, 2016) 
From the data presented in table 1, we can see the difference of the total number of the convicted offenders during this ten years period of time (2006-2015) in Macedonia. It is obviously presented the number of young offenders is quite smaller in difference with adult offenders. Also another positive indicator is the decreased number of the minors convicted during the last years. This is another incentive element for analyzing the preventive measure that may have been effective on this reduction of youth crimes in our country especially for the last years! In this point it takes us to give the answers to these two hypothesis:

How effective have preventive measures proved to be against the crime of children in RM?

How much has the aim of the special prevention of the criminal sanctions in convicted children for criminal actions been achieved in Macedonia?

The number of reported, accused and convicted children during the period of 20062015

\begin{tabular}{llll}
$\begin{array}{l}\text { Table } 2 \\
\text { Year }\end{array}$ & Reported & Accussed & Offended \\
\hline 2006 & 1500 & 987 & 844 \\
2007 & 1229 & 839 & 676 \\
2008 & 1355 & 981 & 715 \\
2009 & 1519 & 1030 & 748 \\
2010 & 1244 & 750 & 547 \\
2011 & 1163 & 1002 & 722 \\
2012 & 1001 & 778 & 556 \\
2013 & 1005 & 657 & 473 \\
2014 & 972 & 712 & 461 \\
2015 & 772 & 465 & 348 \\
\hline
\end{tabular}

Table 2 (State Statistical Office of the Republic of Macedonia, 2016)

In Table n. 2 we can see the number of reported children, those accused and those convicted for each year, from which we can clearly see the difference in numbers of criminal acts from one phase of criminal procedure to another, thus showing that not every single criminal case that is initiated with criminal charges in the preliminary stage will reach the accusatory stage; and also not every issue prefixed with charges will reach the judicial review, namely will be concluded by a sentencing decision/court verdict! And this fact is especially taken into account when it comes to a suspect, an accused or a defendant who is a child, taking into consideration the special and pivileged treatment that children have throughout the criminal-legal system, with the sole purpose - protection of the child's interest!

Table 3 Number of convicted children in the Republic of Macedonia during the period of 2006-2015 and the number of convicted female children during the same period

\begin{tabular}{|l|l|l|l|l|l|l|l|l|l|l|}
\hline $\begin{array}{l}\text { Year } \\
\text { Total }\end{array}$ & $\mathbf{2 0 0 6}$ & $\mathbf{2 0 0 7}$ & $\mathbf{2 0 0 8}$ & $\mathbf{2 0 0 9}$ & $\mathbf{2 0 1 0}$ & $\mathbf{2 0 1 1}$ & $\mathbf{2 0 1 2}$ & $\mathbf{2 0 1 3}$ & $\mathbf{2 0 1 4}$ & $\mathbf{2 0 1 5}$ \\
\cline { 2 - 12 } & 844 & 676 & 715 & 748 & 547 & 722 & 556 & 473 & 461 & 348 \\
\hline Females & - & 24 & 38 & 49 & 20 & 22 & 9 & 24 & 16 & 22 \\
\hline
\end{tabular}

(Perpetrators of criminal offences in 2014, Skopje, 2015, Statistical review / State statistical office of the Republic of Macedonia, Population and social statistics,2.4.16.08)

In Table n. 3, the number of convicted children in the Republic of Macedonia for the duration of the time period specified in the research is shown, while specifying the number of the total number of the convicted children for each year as well as the number of female children that have been convicted during this time period. In 2006 we have 844 convicted children, in 2007 a total of 676 convicted children, in 2008 a total of 715 convicted children, in 2009 a total of 748 convicted children, in 2010 a total of 547 convicted children, in 2011 a total of 722 convicted children, in 2012 a total of 556 convicted children, in 2013 a total of 473 convicted children, in 2014 a total of 461 convicted children, and in 2015 a total of 348 convicted children. Something that can be noticed immediately in this table is the fact that there is a tendency of decline in ht $\mathrm{e}$ numbers of convicted children in our country, during the last few years, especially if we make a comparison between the first years that this research covers and the last years, where we see that the number of convicted children has decreased by $50 \%$. (Arifi, 2017) 
Another indicator in Table n.2 reflects the number of female children that have been convicted, compared to the total number of convicted children. In this case as well it is hardly impossible to notice the relation of the children from both genders, in the context of their inclination to committing criminal acts. We can see a very small number of female children convicted along the ten year period that the research covers compared to that of male children. Namely, for 2006 from a total of 844 convicted children, there are no published data in the State Statistical Office of the Republic of Macedonia for the number of convicted female children; In 2007 from a total of 676 convicted children only 24 are female children. In 2008 from a total of 715 only 38 female children are convicted for criminal offence; During 2009 from a total of 748 only 49 female children are convicted; During 2010 from a total of 547 convicted children only 20 were females; During 2011 from a total of 722 convicted children only 22 were females; During 2012 from a total of 556 convicted children only 9 females; In 2013 from a total of 473 convicted children only 24 are females; In 2014 from a total of 461 convicted children only 16 were females and in 2015 from a total of 348 convicted children only 22 of them were. (Arifi, 2017)

Thus, from these numbers we can conclude that the female minors, namely the children belonging to the female gender, are less included compared to the male children to commit criminal act, and this can be seen in the very small percentage of convicted female children during the period of 2007-2015. Also, if we can say that the overall number of convicted children has positively decreased in the last years, the same cannot be said specifically for the number of convicted female children, because as we can see in the table this number has e relatively stable state with an average that fluctuates between 20 to 40 female children convicted during the year. This tendency of decline of the number of the convicted children from 20122013 and onwards, can be related to some dilemmas, or solutions, like for example priority in pronunciation by competent authorities and in enforcement of noncriminal measures against children - assistance and protection measures, which might have contributed to the decrease of the number of convicted children, given that these non-criminal measures were imposed on them. Thus, it is possible that the number of convictions has decreased rather than the criminal phenomenon of children in the country. This question can be somewhat cleared up if we analyze the number of reported children, namely children towards whom criminal charges were raised during the years of research in table. 1. However, we can normally analyze other factors that might have influenced the decrease of the number of convicted children, such as the preventive measures on child crime, which might have actually yielded success in decreasing the criminality of children these past years! (Arifi, 2017)

\section{The legal regulations for prevention of the children's crime}

\section{The Law on Justice for Children}

The positive law which regulates the criminal law for children in Republic of Macedonia (for all persons 7 - 18 years old), on its sixth part titled "Prevention of children's delinquency", articles 154-159 regulates the issues for the competent public organs for working on preventing the youth crime. (Law on Justice for Children of Republic of Macedonia, 2013) There is established a special public organ named The State Council for the Prevention of Children's Crime. This State Council shall be independent and independent in the performance of the activities determined by this law. It is composed of 15 members elected by the Parliament of the Republic of Macedonia for a term of five years, with the right to re-election, of which: seven members of the State Council are proposed by the Minister of Justice and are representatives of the Ministry of Justice, The Ministry of Labor and Social Policy, the Ministry of Education and Science, the Ministry of Interior Affairs, the Public Prosecutor's Office of the Republic of Macedonia, the Supreme Court of the Republic of Macedonia and the Bar Association of the Republic of Macedonia; Eight members of the State Council are selected by ranks of a public announcement, among the prominent scientific and professional workers who are working on the protection of the interests of the children, one of which is from the ranks of the non-governmental organizations for the protection of children. The State Council shall have its seat in the Ministry of Justice and a representative from the Ombudsman shall participate in the work of the Council. (Law on Justice for Children of Republic of Macedonia, 2013)(art. 154)

The state administration bodies, courts, public prosecutors, as well as legal persons who perform public authorizations in the area of schooling, education and protection of children, are obliged to cooperate with the State Council for the accomplishment of its functions. (art 155).

The State Council has the following competencies:

\section{- Adopts the National Strategy for the Prevention of Child Offense,}

- Approves programs and annual plans for the implementation of the program, 
- Adopts a Regulation for its work,

- Proposes funds in the budget calculation proposal of the Ministry of Justice necessary for his work,

- Provides initiatives to improve legal solutions and opinions on draft laws that are important for the protection of children's rights and prevention of child offenses,

- Launches initiatives for broader recognition of citizens with children's rights and debates on healthy families, protection of children from narcotics, alcoholism and other addiction diseases, education and education issues, public relations media and for other factors that influence the prevention of child offenses,

- Initiates research and studies on child offense problems,

- Cooperates with international organizations and bodies engaged in the protection of children's rights and prevention of child delinquency,

- Prepares annual reports on its work and situation in the area of children's rights and child delinquency, which it submits to the Parliament and the Government of the Republic of Macedonia, the Judicial Council and the Supreme Court of the Republic of Macedonia - who are obliged to review and take appropriate measures and activities in accordance with their competences (art. 156)

The Council of Municipalities, Municipalities of the City of Skopje and the City of Skopje appoints the Municipal Council and the City Council of Skopje to Prevent Child Delinquency. (art.158,1.) Municipal councils adopt annual programs for their work approved by municipal councils and the City Council of Skopje, regulations for its work in the region of the municipality and the city of Skopje, perform work to monitor the situation, set up an initiative for upgrading them and developing programs to involve the local community in preventing child delinquency and treating perpetrators of actions that are foreseen as a criminal offense and misdemeanor by law. The municipal councils, at least once a year, inform the council of the municipality or the city of Skopje and the State Council for Prevention of Child Delinquency. (art.159).

\section{National Strategy for Juvenile Prevention (2010-2020)}

This is the first strategy in the Republic of Macedonia aimed at determining the strategic guidelines and priorities for preventing juvenile delinquency and has been adopted by the State Council for the Prevention of Juvenile Delinquency. (Golomeova, 2013) 1

The integral part of this Strategy are: (National Strategy for Juvenile Prevention (2010-2020) of R.M.)

- Prevention of juvenile delinquency is an essential part of prevention of crime in society;

- The successful prevention of juvenile delinquency requires efforts by the whole society to ensure a harmonious development of adolescents, with respect and promotion of their personality since the earliest childhood;

- Young people should have an active role in society and should be considered as subjects, and not as passive objects of socialization or control;

- The focus of any preventive program should be the well-being of young people from their early childhood;

- Policies and measures of prevention should avoid stigmatization and punishment of children who with their behavior do not cause serious harm to their own development or development of others, but rather endeavor to understand the problem and accept the responsibility for the child;

- Prevention services and programs should be developed locally and supported by the community.

The main challenges and strategic guidelines identified in this

Strategy refer to the primary, secondary and tertiary

\footnotetext{
${ }^{1}$ http://eprints.ugd.edu.mk/10409/1/MAGISTERSKA\%20PDF.pdf
} 
prevention. Namely, the objectives of this Strategy are to introduce programs for prevention of juvenile delinquency, coordination, organization and multidisciplinary approach to this issue, assessing and assessing factors that increase juvenile delinquency, as well as intensive international cooperation in the field of prevention of juvenile delinquency. (Golomeova, 2013)

\section{Analysis of some social factors as preventive measures for youth crime:}

The following presented results are based in the Survey made on September 2017 in three secondary schools in Macedonia, with 120 pupils ages $15-18$ years old. The nature of the questions of the questionnaire were formulated based on the assessment of the impact of some social factors that can most often influence the appearance of the deviant and criminal actions among young people. Also in the other hand the same factors can appear as preventive measures on the criminal behavior of the young people.

The focus of the questions was on the following factors:

The influence of the educational system, respectively how much widespread violence in schools is and how much endangered / protected are students at school!

What preventive measures do schools take to prevent deviant actions of young people?

The influence of the family on young people.

The influence of the circle of people with whom young people are associated,

The free time (after school activities)

Media mass (TV, Internet etc.)

\section{Here are some results from the survey:}

The School effect on preventing crime:

Have you ever listended to any lecture/ project during your studies on

preventing youth crime?
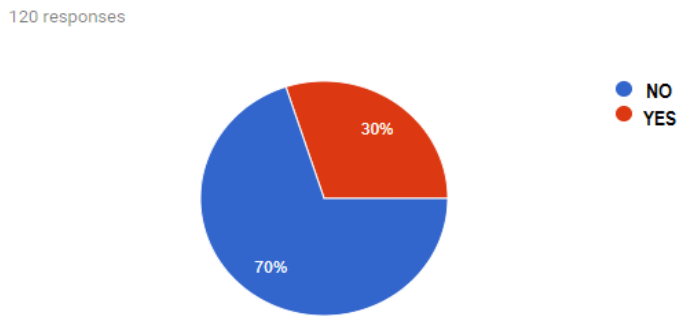

On the question on have the pupils have attended to any lecture on how to prevent crime, most of them (70\%) have replies with No, and only $30 \%$ have answered Yes. It was obvious that only in one of the three schools the study was made, there haw been some programs on informing the children on how to prevent crime. And it, was reported that there have been some police officers who have held lectures to the pupils on what behaviors are crimes based on the countries legislation and some other aspects on how to prevent these acts. But, the negative indicator is that in the most cases, the respondents were not informed about this topic! 


\section{How often you have meetings with the pedagogue / psychologist of the school?}

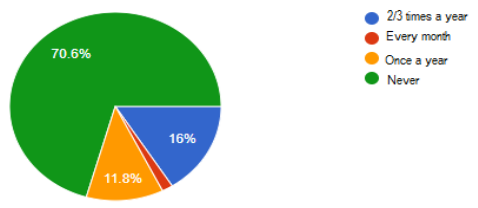

The other question about how often do the students have meetings/consultations with the competent persons in their schools for giving to them advices and support, as the pedagogue and the psychologist, the answers were desperate. $70.6 \%$ of the students answered that they never meet these personnel of the school, and the others answered with once a year or $2 / 3$ times a year. This results are also desperate, because there is indisputable the role of the pedagogue and the psychologist in the schools. Having in consider the age of the students in secondary schools it is unjustified the passivity of these persons on doing/not doing their job!

\section{Do you think it should be increased the security in the school?}

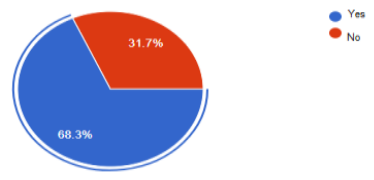

On the question did the students think that it should be increased the level of security in their school, we came with results of $68.3 \%$ who said Yes, and $31.7 \%$ who said No. It means that most of the students do not feel safe in their schools. The schools should take more strict and rigorous measures on protecting their students and making them feel same during their stay there.

\section{Do you have too much free time after finishing your classes?}

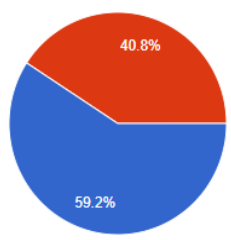

Yes

On the question on did the students consider that they have too much free time after finishing the classes, we came with results that $59.2 \%$ answered Yes, and the others consider that they do not have much free time after school. This question is made with the aim to get answers and be confirmed our hypothesis that in Macedonia the children have much free time, and that this is one of the factors that indicates the appearance of the deviant acts of the young people. There are not such opportunities for free activities where the youth can spend the time after schooling. For ex. The students who finish their 
classes about 13.30 p.m. they do not really have some opportunities offered by the state or the school where they can be involved. And, that is why it often happens they the young people spend their free time on coffee bars and can be involved on negative/criminal acts where they meet adults who can easily manipulate and incriminate them in different acts, like drug trafficking, alcohol usage, theft, group fighting etc.!

\section{How much influence does your family has on your behavior?}

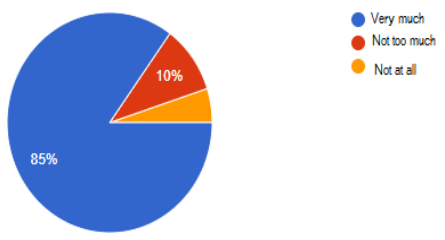

On the question about the influence of the family on the behavior of the youth people, it is again proved that the family is the main factor in preventing the delinquency of juveniles. That is because $85 \%$ of the students answered that their family has very much influence on their behavior, and the other less of them said that the family has not too much influence on them and the smallest number of the respondents answered that the family does not have influence at all on them!

\section{How much important is what your friends think about vou/vour behavior?}

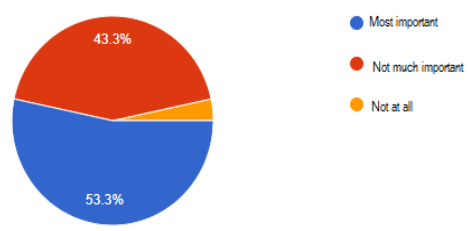

On the question about what the friends opinion means to the young people, $53 \%$ answered that it is most important what their friends think about them or their behavior. \$3.3\% answered that it is not much important their friend opinion and only $4 \%$ of them do not care of the friends opinion. It is proved that in most cases the delinquent acts are presented in the young population only because they are part of one or another group in their school!

\section{Can you get inspired on making a negative behavior from the Internet information you get?}

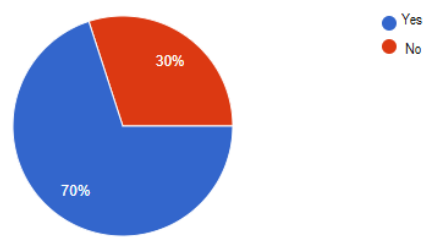


On the question about the influence of the Internet information on the young people's behavior, we got $70 \%$ positive answers that Internet can be an inspirational/motivational tool for manifesting a negative act. Only $30 \%$ of the respondent said that they can not be inspired from the Internet on acting negatively, respectively to commit any delinquent or criminal act. This is also another indicator that Internet can be often the most preventive tool for youth crimes or the opposite-provocative factor for criminal acts.

\section{Conclusion}

Preventing youth crime can be done only if there a cooperation between all the competent state institutions on improving the social conditions for the youth people's welfare. It is better to prevent rather than to correct and in Macedonia there has to be much done on more aspects for reducing and preventing youth crime.

\section{Bibliography}

[1] Arifi, B. (2017). THE CHILD CRIME PHENOMENON IN REPUBLIC OF MACEDONIA: 2006-2015. ANNUAL of ISPJR , XLI (I), 103-104.

[2] Golomeova, E. (2013). Превенција на малолетничка деликвенција, анализа на законската регулатива и пракса. Shtip: Faculty of Law, University "Goce Delcev".

[3] Law on Justice for Children of Republic of Macedonia. (2013). "Official Gazette of R.M." no. 148.

[4] National Strategy for Juvenile Prevention (2010-2020) of R.M. (n.d.).

[5] State Statistical Office of the Republic of Macedonia. (2016). Perpetrators of criminal offenses in 2015. Skopje: State Statistical Office of the Republic of Macedonia.

[6] Perpetrators of criminal offences in 2012, Skopje, 2013, Statistical review / State statistical office of the Republic of Macedonia, Population and social statistics 2.4.14.11 (789)

[7] Perpetrators of criminal offences in 2013, Skopje, 2014, Statistical review / State statistical office of the Republic of Macedonia, Population and social statistics 2.4.14.11 (789)

[8] Perpetrators of criminal offences in 2014, Skopje, 2015, Statistical review / State statistical office of the Republic of Macedonia, Population and social statistics 2.4.15.12 (823)

[9] Perpetrators of criminal offences in 2015, Skopje, 2016, Statistical review / State statistical office of the Republic of Macedonia, Population and social statistics 2.4.16.08 (854) 